Article

\title{
Unexpected Role of Sterol Synthesis in RNA Stability and Translation in Leishmania
}

\author{
Zemfira N. Karamysheva ${ }^{1, *}$, Samrat Moitra ${ }^{1}$, Andrea Perez ${ }^{1,2}$, Sumit Mukherjee ${ }^{1,3}$, Elena B. Tikhonova ${ }^{4}$, \\ Andrey L. Karamyshev ${ }^{4}$ and Kai Zhang ${ }^{1, *}$ (B)
}

1 Department of Biological Sciences, Texas Tech University, Lubbock, TX 79409, USA; samrat.moitra@ttu.edu (S.M.); andrea.perez@ttu.edu (A.P.); sumit.mukherjee@wustl.edu (S.M.)

2 Honors College, Texas Tech University, Lubbock, TX 79409, USA

3 Division of Infectious Diseases, Department of Medicine, Washington University School of Medicine, St. Louis, MO 63110, USA

4 Department of Cell Biology and Biochemistry, Texas Tech University Health Sciences Center, Lubbock, TX 79430, USA; elena.tikhonova@ttuhsc.edu (E.B.T.); andrey.karamyshev@ttuhsc.edu (A.L.K.)

* Correspondence: zemfira.karamysheva@ttu.edu (Z.N.K.); kai.zhang@ttu.edu (K.Z.); Tel.: +1-806-834-5075 (Z.N.K.); +1-806-834-0550 (K.Z.)

\section{check for}

updates

Citation: Karamysheva, Z.N.; Moitra, S.; Perez, A.; Mukherjee, S.; Tikhonova, E.B.; Karamyshev, A.L.; Zhang, K. Unexpected Role of Sterol Synthesis in RNA Stability and Translation in Leishmania. Biomedicines 2021, 9, 696. https://doi.org/ 10.3390/biomedicines9060696

\section{Academic Editors:}

Gabriela Santos-Gomes and Maria Pereira

Received: 18 May 2021

Accepted: 15 June 2021

Published: 19 June 2021

Publisher's Note: MDPI stays neutral with regard to jurisdictional claims in published maps and institutional affiliations.

Copyright: (c) 2021 by the authors. Licensee MDPI, Basel, Switzerland. This article is an open access article distributed under the terms and conditions of the Creative Commons Attribution (CC BY) license (https:// creativecommons.org/licenses/by/ $4.0 /)$.

\begin{abstract}
Leishmania parasites are trypanosomatid protozoans that cause leishmaniasis affecting millions of people worldwide. Sterols are important components of the plasma and organellar membranes. They also serve as precursors for the synthesis of signaling molecules. Unlike animals, Leishmania does not synthesize cholesterol but makes ergostane-based sterols instead. C-14demethylase is a key enzyme involved in the biosynthesis of sterols and an important drug target. In Leishmania parasites, the inactivation of C-14-demethylase leads to multiple defects, including increased plasma membrane fluidity, mitochondrion dysfunction, hypersensitivity to stress and reduced virulence. In this study, we revealed a novel role for sterol synthesis in the maintenance of RNA stability and translation. Sterol alteration in C-14-demethylase knockout mutant leads to increased RNA degradation, reduced translation and impaired heat shock response. Thus, sterol biosynthesis in Leishmania plays an unexpected role in global gene regulation.
\end{abstract}

Keywords: Leishmania; sterol; C-14-demethylase; stress tolerance; RNA degradation; polysome; endoplasmic reticulum; translation; regulation of gene expression

\section{Introduction}

Protozoan parasites of the genus Leishmania cause leishmaniasis infecting 10-12 million people worldwide [1]. There are three major forms of leishmaniasis. Visceral leishmaniasis is the most severe form, with a mortality rate of almost $100 \%$ if left untreated [2,3]. Mucocutaneous leishmaniasis can produce disfiguring lesions of the nose, mouth and throat cavities. The cutaneous form of leishmaniasis is the most common type representing $50-75 \%$ of all new cases [4].

All three forms of leishmaniasis are transmitted through the bite of sand fly vectors (Phlebotomus spp. and Lutzomyia spp.). During their life cycle, these dixenic protozoans alternate between flagellated, extracellular promastigotes, which live in the midgut of sand flies, and non-flagellated amastigotes residing in the phagolysosomal compartment of mammalian macrophages [5]. Promastigotes are transmitted with sand fly saliva into the mammalian host during blood feeding, where they are rapidly engulfed by phagocytic cells and differentiate into amastigotes. The changes in temperature, $\mathrm{pH}$ and nutrients that Leishmania parasites encounter in the mammalian host appear to be essential for the promastigote to amastigote differentiation [6]. Options for leishmaniasis control are very limited due to the lack of a vaccine, toxic side effects of drugs and rapid emergence of drug-resistant strains $[7,8]$. Therefore, there is an urgent need to understand the molecular 
mechanisms utilized by Leishmania parasites to survive in different hosts, as discoveries in basic biology can lead to new medicine.

Lipid metabolism is a very important yet understudied area in protozoan parasites. Besides serving as an energy source and building blocks of the membrane, lipids are implicated in parasite-host interaction and pathogenesis [9-11]. Drugs such as miltefosine and antimony induce lipid perturbations which contribute to the development of drug resistance in Leishmania parasites [12,13]. Notably, Leishmania parasites produce different types of sterols from humans, making the sterol synthesis pathway an attractive pharmacological target $[14,15]$. Specifically, Leishmania produces ergostane-based sterols such as ergosterol and 5-dehydroepisterol while human cells synthesize cholesterol [16]. Sterols are important constituents of the plasma membrane (PM), endoplasmic reticulum (ER) and organellar membranes. Because of their rigid and hydrophobic structure, sterols reduce the flexibility of acyl chains of neighboring phospholipids and increase membrane rigidity and tightness [17]. They are also involved in vesicular transport [17]. Sterols defects are known to affect not only membrane permeability and fluidity but also the localization of membrane-bound proteins and transport of proteins [18]. In mammalian cells, the distribution of sterols in specific organellar membranes is strictly regulated, and its impairment leads to many diseases [19]. In yeasts, defects in sterol synthesis lead to disruption in ER organization and changes in lipid organization of the PM [20].

C-14-demethylase (C14DM) catalyzes the removal of a methyl group from the carbon14 position of lanosterol, a key step in the synthesis of ergostane-based sterols [21]. The C14DM-null mutant $\left(c 14 \mathrm{dm}^{-}\right)$has been characterized in Leishmania major LV39 strain [22]. This mutant cannot remove the C-14-methyl group from lanosterol or other sterol intermediates. The defect leads to increased membrane fluidity, mitochondrion dysfunction, superoxide accumulation, hypersensitivity to heat and severely reduced virulence in mice $[22,23]$.

In this study, we revealed an unexpected role of C14DM in the regulation of RNA levels in Leishmania parasites. We uncovered that defects in sterol synthesis lead to reduced RNA stability and protein synthesis, which likely contribute to their impaired stress response. Our study is the first of its kind that links sterol synthesis to the global regulation of gene expression at the level of RNA stability.

\section{Materials and Methods}

\subsection{Reagents}

Actinomycin D and MitoSox Red were purchased from Sigma (St. Louis, MO, USA) and Thermo Fisher Scientific (Waltham, MA, USA), respectively. Trizol and Trizol LS were purchased from Life Technologies (Carlsbad, CA, USA). L-Glutathione (reduced form) and antimycin A were purchased from ENZO Life Sciences (Farmingdale, NY, USA). All other chemicals were purchased from VWR International (Radnor, PA, USA) unless otherwise specified.

\subsection{Leishmania Culturing and Treatments}

Leishmania major LV39 (Rho/SU/59/P), c14dm- (C14DM-null mutant) and c14dm- / + C14DM (episomal add-back) promastigotes were cultivated at $27^{\circ} \mathrm{C}$ in complete M199 media containing $10 \%$ fetal bovine serum and additional supplements as previously described [24]. Culture densities over time were determined by direct cell counting using a hemacytometer. The BCA protein assay kit (Thermo Fisher Scientific) was used to determine protein concentration in cell lysates according to the manufacturer's recommendation. In order to block transcription and monitor RNA degradation, actinomycin $\mathrm{D}$ was added at $10 \mu \mathrm{g} / \mathrm{mL}$ to mid-log phase cultures $\left(3-6 \times 10^{6}\right.$ cells $\left./ \mathrm{mL}\right)$. Equal aliquots of cultures were taken at the indicated times for further analysis.

Some experiments required antioxidant treatment of cells. Briefly, Leishmania promastigotes were seeded at $4 \times 10^{5}$ cells $/ \mathrm{mL}$ and treated with different concentrations of L-glutathione (1, 2 or $4 \mathrm{mM})$ for $48 \mathrm{~h}$ prior to cell collection for further analysis. In 
order to induce mitochondrial oxidative stress, LV39 wild-type (WT) cells prepared at a concentration of $1.0 \times 10^{7}$ cells $/ \mathrm{mL}$ were treated with $5 \mu \mathrm{M}$ of antimycin A for $3 \mathrm{~h}$ at $27{ }^{\circ} \mathrm{C}$. Then parasites were stained with $10 \mu \mathrm{M}$ of MitoSox Red. Mean fluorescence intensities (MFI) were determined by flow cytometry using an Attune NxT Acoustic Flow Cytometer (Thermo Fisher Scientific) to confirm the induction of mitochondrial stress prior to cell collection for downstream analysis. Cell viability was determined by measuring the incorporation of propidium iodide (PI, $5.5 \mu \mathrm{g} / \mathrm{mL}$ ) via flow cytometry as described [23]. Neither antimycin A nor L-glutathione treatments significantly affected cell viability based on PI staining ( $<5 \%$ PI positive).

\subsection{Polysome Profiling}

Polysome profiling experiments were performed as published earlier [25]. Briefly, Leishmania promastigotes of WT, $c 14 \mathrm{dm}^{-}$and $c 14 \mathrm{dm}^{-} /+$C14DM were grown in flasks until cell density reached $5 \times 10^{6}$ cells $/ \mathrm{mL}$. An equal number of cells $\left(1.5 \times 10^{8}\right.$ promastigotes $)$ were used for polysome profiling for each experimental condition. Before lysis, cells were treated with $100 \mu \mathrm{g} / \mathrm{mL}$ of cycloheximide for $15 \mathrm{~min}$ at $27^{\circ} \mathrm{C}$ to stabilize ribosomes on mRNAs. Cells were lysed on ice in a buffer containing $20 \mathrm{mM}$ Hepes-KOH (pH 7.5), $10 \mathrm{mM} \mathrm{MgCl}_{2}, 100 \mathrm{mM} \mathrm{KCl}, 2 \mathrm{mM}$ DTT, 1\% NP-40, $1 \times$ protease inhibitor cocktail (EDTAfree) from Sigma, 200 units/mL RNasin (Thermo Fisher Scientific) and $100 \mu \mathrm{g} / \mathrm{mL}$ of cycloheximide. Details of cell lysate preparation were described previously [25]. The lysate was clarified by centrifugation at $11,200 \mathrm{~g}$ for $10 \mathrm{~min}$ at $4{ }^{\circ} \mathrm{C}$. In order to separate polysomes, $500 \mu \mathrm{L}$ of the clarified lysate was loaded on top of a $10 \%-50 \%$ sucrose gradient containing $20 \mathrm{mM}$ Hepes-KOH (pH 7.5), $100 \mathrm{mM} \mathrm{KCl}, 10 \mathrm{mM} \mathrm{MgCl}_{2}, 1 \mathrm{mM}$ DTT and 200 units/mL RNasin, and subjected to ultracentrifugation using an SW41 rotor for $2 \mathrm{~h}$ at 260,000×g and $4{ }^{\circ} \mathrm{C}$. After centrifugation, $500 \mu \mathrm{L}$ of fractions were collected using a Piston Gradient Fractionator from BioComp Instruments (Fredericton, NB, Canada). Trizol LS was added to fractions immediately, and samples were stored at $-80^{\circ} \mathrm{C}$ until RNA extraction.

\subsection{RNA Extraction, cDNA Preparation and Real-Time Reverse-Transcription Quantitative PCR (RT-qPCR)}

Total RNA was isolated using Trizol or Trizol LS (for polysomal fractions) and quantified spectrophotometrically using a NanoDrop device (Thermo Fisher Scientific) as described [25]. cDNA samples were prepared using a High-Capacity cDNA Reverse Transcription Kit from Applied Biosystems (Waltham, MA, USA) according to the manufacturer's recommendation. Real-time quantitative polymerase chain reactions (RT-qPCR) were performed on a Quant Studio 12 K Flex Real-Time PCR System using Power SYBR Green PCR Master Mix (Applied Biosystems), according to the manufacturer's protocol. The comparative $\Delta \Delta C T$ method was used to quantify the qPCR results [26]. For the analysis of gene expression, synthetic outer membrane protein A (OmpA) mRNA was added to all samples prior to RNA extraction and used for normalization as described [25]. The RNA levels were analyzed by RT-qPCR for the following genes: tubulin, heat shock protein 70 (HSP70), heat shock protein 83 (HSP83), sterol-24-C- methyltransferase (SMT), 18S ribosomal RNA (18S rRNA) and $28 \mathrm{~S}$ ribosomal RNA (28S rRNA). The primers used in RT-qPCR reactions and corresponding gene identification numbers are presented in Supplementary File S1.

\subsection{ER Labelling and Confocal Microscopy}

ER staining was performed using an anti-Trypanosoma brucei BiP antibody (kind gift from Dr. Jay Bangs, University at Buffalo, SUNY). Log phase WT, $c 14 \mathrm{dm}^{-}$and $c 14 d m^{-} /+$ $\mathrm{C} 14 \mathrm{DM}$ promastigotes were incubated at $27{ }^{\circ} \mathrm{C}$ (control) or $37^{\circ} \mathrm{C}$ (experimental) for $2 \mathrm{~h}$. Afterwards, parasites were washed in phosphate-buffered saline (PBS), attached to poly-Llysine coated coverslips, fixed with $3.7 \%$ formaldehyde, and then permeabilized on ice with ethanol. Incubation with the rabbit anti-T. brucei BiP antiserum (1:1000) was performed at room temperature for 40 minutes. After washing with PBS, coverslips were incubated with a goat anti-rabbit-Alexa Fluor 488 (1:2000) antiserum for $40 \mathrm{~min}$. An Olympus (Center Valley, PA, USA) Fluoview FV3000 Laser Scanning Confocal Microscope was used to visualize the 
intensity and localization of BiP from randomly selected cells using the cellSens Imaging Software (Olympus). The number of cells analyzed at $27^{\circ} \mathrm{C}$ was 63 (WT), $131\left(\mathrm{c} 14 \mathrm{dm}^{-}\right)$and $95(\mathrm{c} 14 \mathrm{dm}-/+\mathrm{C} 14 \mathrm{DM})$. The number of cells analyzed at $37^{\circ} \mathrm{C}$ was $152(\mathrm{WT}), 106\left(\mathrm{c} 14 \mathrm{dm}^{-}\right)$ and $65\left(c 14 d m^{-} /+\right.$C14DM).

\subsection{Statistical Analysis}

Unless specified otherwise, assay values in all figures are averaged from three independent biological repeats, and error bars represent standard deviations. The Student's $t$-test was used in pairwise comparisons. Differences among multiple groups were assessed by One-way Anova followed by Tukey's or Dunnett's test. $p$-values indicating statistical significance were grouped in figures as ns: not significant; ${ }^{*}: p<0.05 ;{ }^{* *}: p<0.01$; and $* * *: p<0.001$.

\section{Results}

\subsection{Defects in Sterol Synthesis Lead to Global Reduction in RNA and Protein Levels in c14dm-}

$\mathrm{C} 14 \mathrm{DM}$ is an important enzyme in ergosterol biosynthesis and the target of azole drugs. In L. major, this enzyme is mostly localized at the ER, and only a minor amount is found in the mitochondrion [22]. Genetic or chemical inactivation of C14DM led to a complete loss of ergostane-based sterols and accumulation of C-14-methylated sterols [22]. c14dm mutants also displayed increased membrane fluidity, reduced virulence and extreme sensitivity to stress.

In order to fully understand the consequences caused by defective sterol synthesis, we examined the total RNA and protein levels in $c 14 \mathrm{dm}^{-}$. Remarkably, we found an approximately $40 \%$ reduction in total RNA levels in $c 14 d m^{-}$in comparison to WT and add-back parasites (Figure 1A). The mutant also had 20\% less total protein (Figure 1B). These results suggest a global dysregulation of gene expression in the cells defective in sterol production. Adding C14DM back completely rescues the defects at both RNA and protein levels.

A

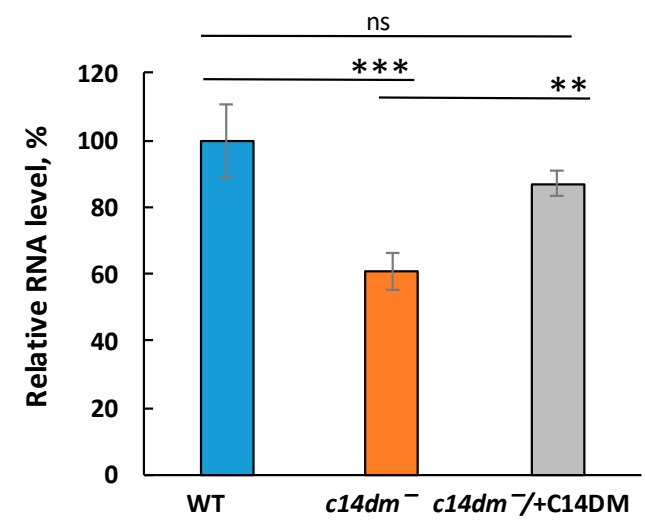

B

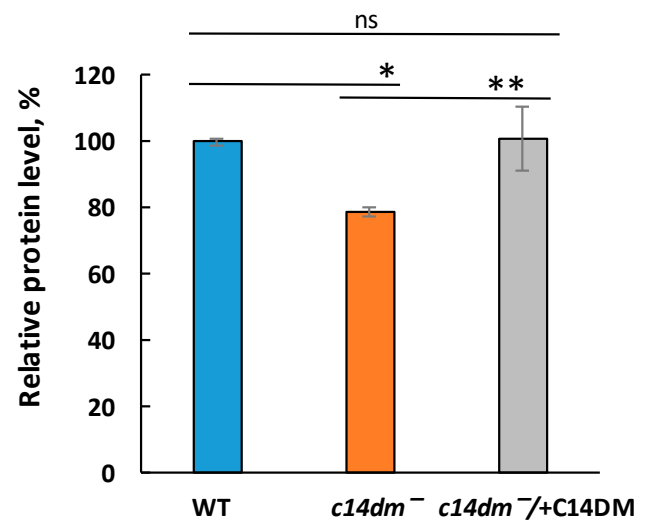

Figure 1. The total RNA and protein levels are reduced in $c 14 d m^{-}$mutant. (A) The total RNA was extracted from $1 \times 10^{7}$ cells of WT, $c 14 \mathrm{dm}^{-}$and $c 14 \mathrm{dm}^{-} /+$C14DM cells and quantified using NanoDrop in relation to WT. (B) The total protein levels from $1 \times 10^{7}$ cells of WT, $c 14 \mathrm{dm}^{-}$and $c 14 \mathrm{dm}^{-} /+\mathrm{C} 14 \mathrm{DM}$ were measured using BCA assay, and their relative levels were calculated in relation to WT. ns: not significant; ${ }^{*}: p<0.05 ;{ }^{* *}: p<0.01$; and ${ }^{* * *}: p<0.001$.

In eukaryotic cells, most RNA is rRNA, while the protein-encoding mRNA constitutes about $5 \%$ of total RNA $[27,28]$. Global reduction in RNA level suggests that rRNA is likely reduced. In the next experiment, we examined what type of RNA is affected by defects in sterol synthesis. Total RNA was extracted, and RT-qPCR was performed to measure levels of selected RNAs as described [25]. We found that both $28 \mathrm{~S}$ and $18 \mathrm{~S}$ rRNA, as well as 
individual mRNAs for tubulin and HSP83, displayed substantially lower levels in $\mathrm{c}^{14 \mathrm{dm}^{-}}$ and $c 14 \mathrm{dm}^{-} /+\mathrm{C} 14 \mathrm{DM}$ rescued the defects (Figure 2).
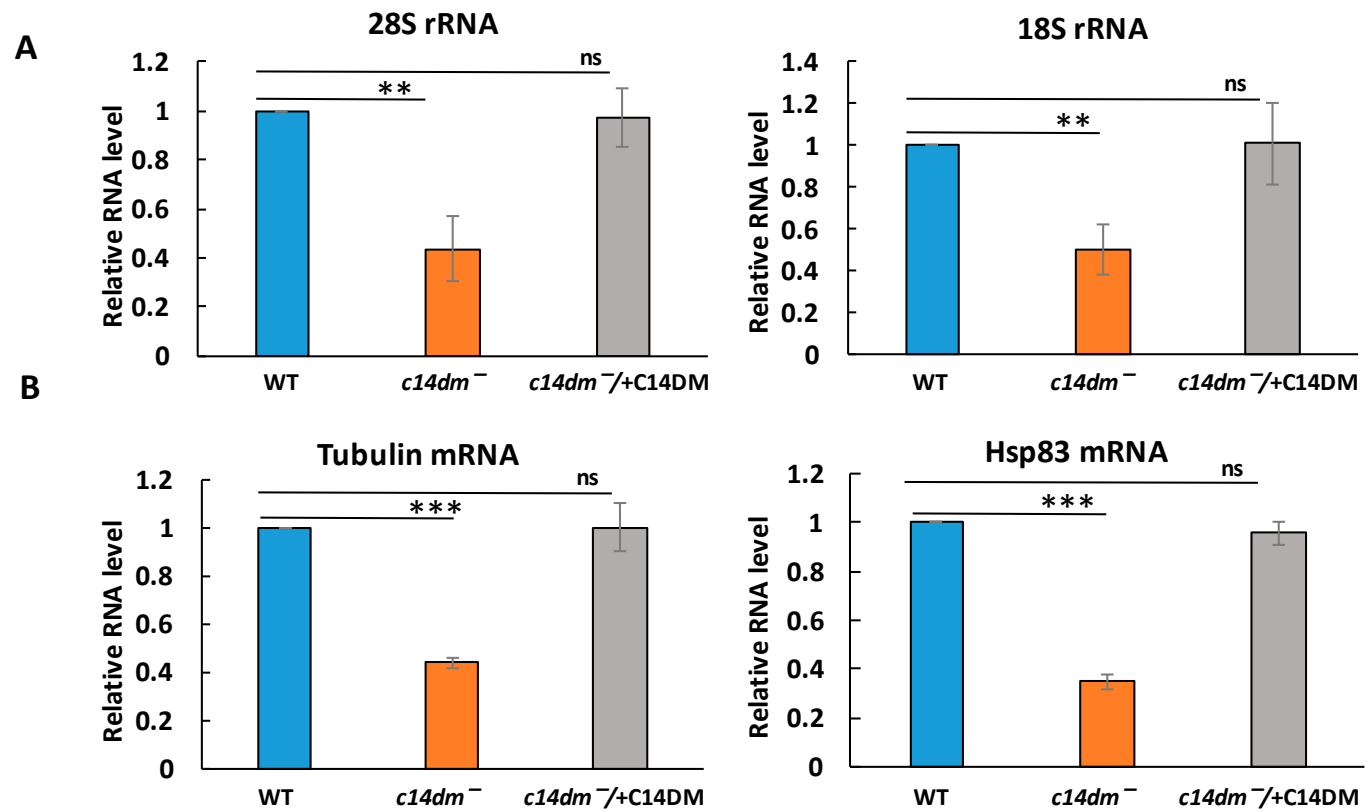

Figure 2. Levels of ribosomal RNA and individual mRNAs are reduced in $c 14 \mathrm{dm}^{-}$. The total RNA was extracted from $1 \times 10^{7}$ cells of WT, $c 14 d m^{-}$and $c 14 d m^{-} /+$C14DM cells. The artificial outer membrane protein A (OmpA) mRNA was added prior to RNA extraction for further normalization. RNA levels were measured by RT-qPCR. (A) 28S (left panel) and 18S (right panel) rRNA levels. (B) Tubulin (left) and HSP83 (right) mRNA levels. ns: not significant; ${ }^{* *}: p<0.01$; and $* * *: p<0.001$.

These results suggest that impairment in sterol biosynthesis causes global downregulation of rRNA and mRNAs in Leishmania major parasites.

\subsection{RNA Stability Is Compromised in c14dm}

The reduction in RNA levels can be caused either by increased RNA degradation or defects in transcription. In order to examine whether defects in sterol synthesis affect RNA stability, we treated WT, $c 14 \mathrm{dm}^{-}$and $c 14 \mathrm{dm}^{-} /+$C14DM cells with actinomycin D to block transcription and monitored the rates of RNA degradation. Actinomycin D inhibits all transcription independent of the types of RNA polymerases [29]. Actinomycin D was added to mid-log phase cells, and a time-course experiment was performed as described in Figure 3. The RNA levels were quantified relative to the starting point of actinomycin D treatment for each strain. The absolute amount of total RNA was lower in $c 14 \mathrm{dm}^{-}$at the starting point (Figure 1B). Our results demonstrate that total RNA decays faster in $c 14 \mathrm{dm}^{-}$ after blocking transcription with actinomycin D, providing strong support to the idea that RNA stability is substantially compromised in the mutant (Figure 3A). We checked the rate of degradation of individual mRNAs as well (Figure 3B). Tubulin mRNA decays much faster in the mutant; after one hour of treatment, only about $57 \%$ of RNA remains in $c 14 \mathrm{dm}^{-}$versus $94 \%$ in WT parasites. HSP83 mRNA exhibits even faster degradation. The half-life of HSP83 mRNA is $48.9 \mathrm{~min}$ in $c 14 \mathrm{dm}^{-}, 137.7 \mathrm{~min}$ in WT and $110.5 \mathrm{~min}$ in $\mathrm{c} 14 \mathrm{dm}^{-} /$ + C14DM parasites, respectively (Figure 3B). 
A

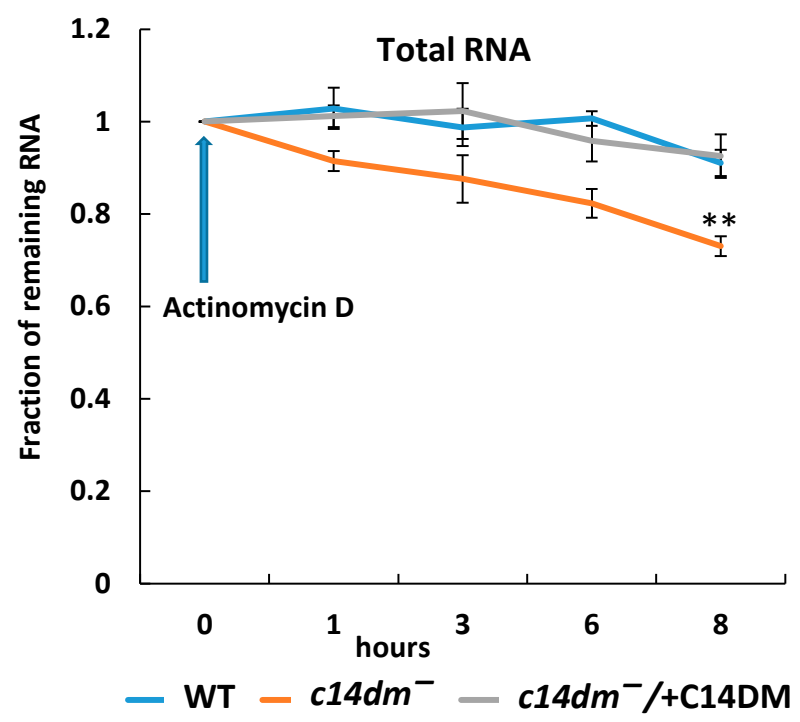

B
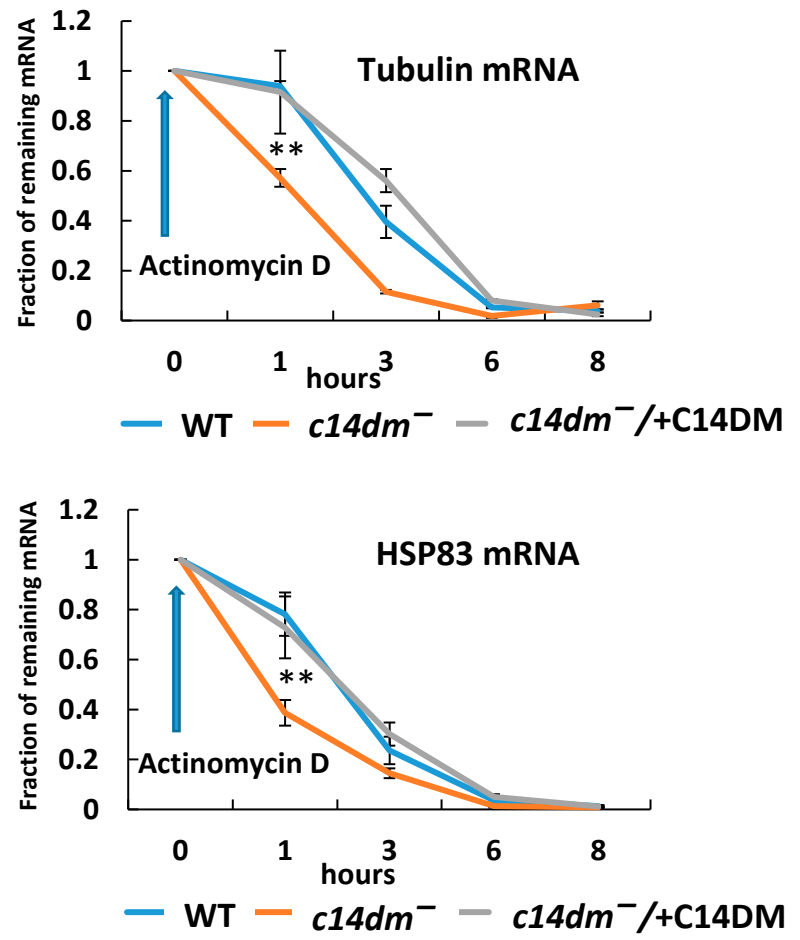

Figure 3. RNA in $c 14 d m^{-}$degrades faster in comparison to WT and add-back parasites. Actinomycin D was added to mid-log cultures, and equal aliquots of cultures were taken at the indicated times. RNA was extracted and analyzed by RT-qPCR relative to the values at the starting point. (A) Total RNA was quantified using NanoDrop over time. (B) The relative abundance of tubulin and HSP83 mRNA was quantified by RT-qPCR over time. ${ }^{* *}: p<0.01$.

We also examined the degradation of $18 \mathrm{~S}$ and 28S rRNA. While rRNA is considered to be more stable, it is also subject to quality control in eukaryotes [30]. It also degrades under conditions of stress or starvation [31]. We have found that $18 \mathrm{~S}$ and $28 \mathrm{~S}$ rRNA degrades significantly faster in the mutant, although they are more stable than tubulin and HSP83 mRNAs (Figure S1).

\subsection{RNA Degrades Faster during Heat Shock and the Induction of Heat Shock Response Is Compromised in $\mathrm{c} 14 \mathrm{dm}^{-}$}

When cells face stress, such as heat shock, a global downregulation of gene expression occurs, but genes involved in stress response to increase survival are selectively upregulated [32]. HSP83 is known to be upregulated in response to heat shock [32]. The $\mathrm{c}^{14 d m^{-}}$ mutant displays extreme sensitivity to stress conditions such as heat shock and starvation $[22,23]$. The ability to cope with stress is essential for Leishmania survival in mammals where they encounter dramatic changes in temperature, nutrient availability and $\mathrm{pH}$ [33]. To examine if the heat shock response is altered in $c 14 \mathrm{dm}^{-}$, we subjected promastigotes to $37^{\circ} \mathrm{C}$ treatment and measured HSP70 and HSP83 mRNA levels by RT-qPCR (Figure 4A,B). Sterol-24-C-methyltransferase (SMT) mRNA and 18S rRNA were included as negative controls, which should not be induced under heat shock (Figure 4C,D). As expected, HSP70 and HSP83 mRNAs showed a 2-4-fold increase in WT parasites after four hours at $37{ }^{\circ} \mathrm{C}$. In contrast, $c 14 \mathrm{dm}^{-}$mutant had a substantially diminished response (1.2-1.5-fold increase after two hours) to the heat shock. This initial increase was fast and significantly dropped down with longer incubation. The defects were completely reversed in $c 14 \mathrm{dm}^{-} /+\mathrm{C} 14 \mathrm{DM}$ cells (Figure 4A,B). We also observed accelerated degradation of SMT mRNA and 18S rRNA in $c 14 \mathrm{dm}^{-}$(Figure $4 \mathrm{C}, \mathrm{D}$ ). After $8 \mathrm{~h}$ of incubation at $37^{\circ} \mathrm{C}$, SMT mRNA level was dramatically diminished to $\sim 5 \%$ in the mutant, whereas only slight changes were detected in WT and $c 14 \mathrm{dm}^{-} /+\mathrm{C} 14 \mathrm{DM}$ parasites. While $18 \mathrm{~S}$ rRNA remained stable in WT and 
add-back parasites even after $8 \mathrm{~h}$ of heat shock, its level was strikingly reduced to $18 \%$ in sterol defective mutant. As previously described [22], $c 14 d m^{-}$parasites were mostly dead after $24 \mathrm{~h}$ of heat shock, while both WT and $c 14 \mathrm{dm}^{-} /+$C14DM parasites were mostly alive by that time and maintained $18 \mathrm{~S}$ rRNA level at around $80 \%$ (Figure 4D,E).

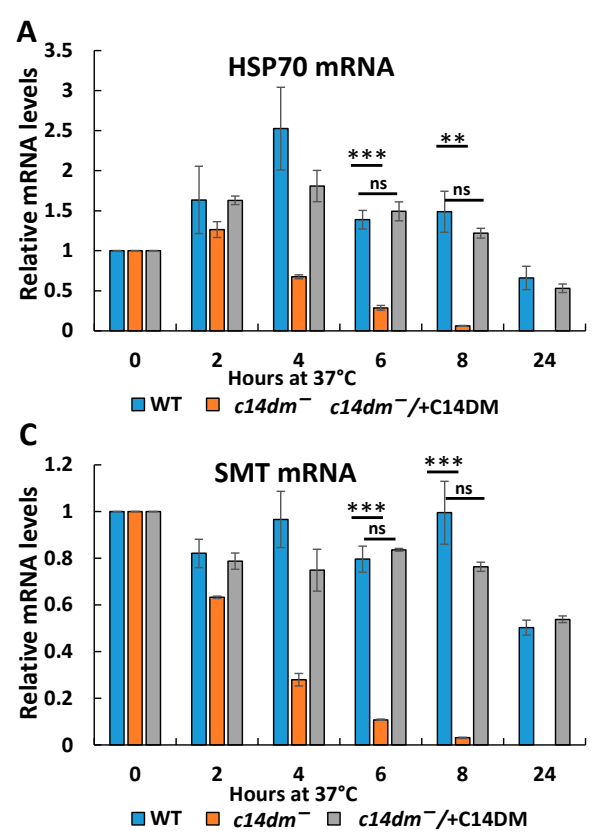

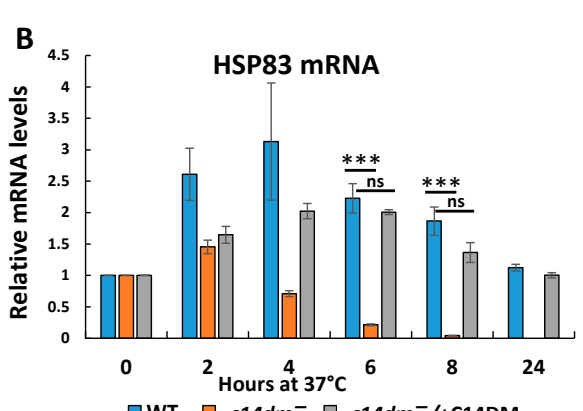

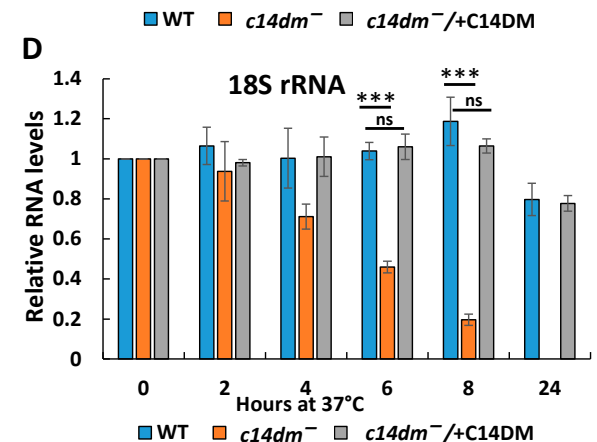

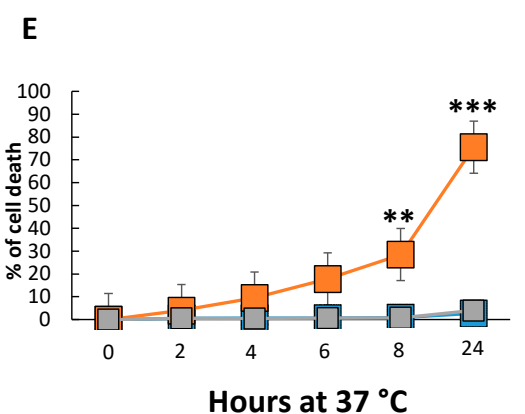

$\neg-\mathrm{WT}-\square-c 14 d m^{-}-\square-c 14 d^{-} /+C 14 \mathrm{DM}$

Figure 4. $C 14 \mathrm{dm}^{-}$mutants show a dramatic decrease in RNA levels during heat shock. Promastigotes were incubated at $37^{\circ} \mathrm{C}$ for $0-24 \mathrm{~h}$, and cells were collected and analyzed at the indicated times. Artificial OmpA mRNA was added prior to RNA extraction for normalization. HSP70 (A), HSP83 (B), SMT (C) mRNA and 18S rRNA (D) levels were measured by RT-qPCR. (E) Cell viability was monitored by PI staining during heat shock. ns: not significant; ${ }^{* *} p<0.01 ;$ and ${ }^{* * *}: p<0.001$.

These results suggest that in addition to increased membrane fluidity and accumulation of superoxide, a defective heat shock response (failure to properly induce HSP gene expression and accelerated degradation of other RNAs) contributes to the extreme heat sensitivity displayed by $c 14 \mathrm{dm}^{-}$(Figure 4E) [22,23].

\subsection{Reduced RNA Levels in c14dm- Is Not Caused by the Accumulation of Oxidants}

$C 14 \mathrm{dm}^{-}$cells have elevated levels of reactive oxygen species (ROS), mostly in the form of mitochondrial superoxide [23]. In order to examine if oxidative stress contributes to the RNA reduction, we cultivated $c 14 \mathrm{dm}^{-}$cells in the presence of L-glutathione and performed total RNA extractions. Cell growth rates and survival (by PI staining) were similar between control and L-glutathione-treated cells (Figure 5A). Importantly, L-glutathione treatment did not restore the RNA levels in $c 14 d m^{-}$(Figure 5B), although it could partially alleviate the ROS accumulation [23].

In addition, L. major WT cells were treated with antimycin A to induce oxidative stress in the mitochondria, and total RNA was extracted from an equal number of cells. While mitochondrial superoxide was induced as expected based on MitoSox staining (Figure 6A) [23], it did not affect the RNA levels (Figure 6B). Cell death was negligible in control and antimycin-treated cells (Figure 6C). 
A

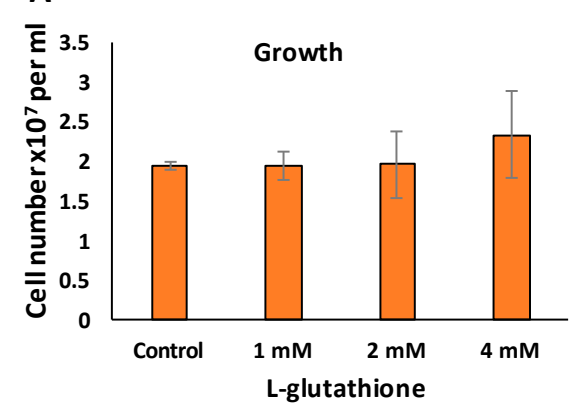

B

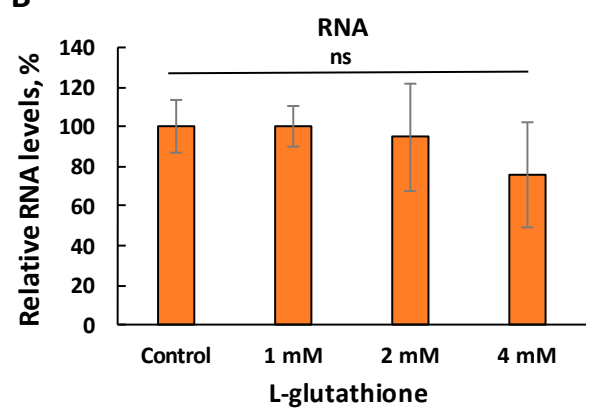

Figure 5. Antioxidant treatment of $c 14 \mathrm{dm}^{-}$mutant does not restore RNA levels. (A) C14dm $\mathrm{m}^{-}$cells were inoculated at $4 \times 10^{5}$ cells $/ \mathrm{mL}$ and treated with $1-4 \mathrm{mM}$ of L-glutathione, and culture densities were determined after $48 \mathrm{~h}$. (B) Total RNA was extracted from $1 \times 10^{7} \mathrm{c} 14 \mathrm{dm}{ }^{-}$cells after L-glutathione treatment and quantified by NanoDrop. Percentages represent RNA levels relative to the untreated control. ns: not significant.
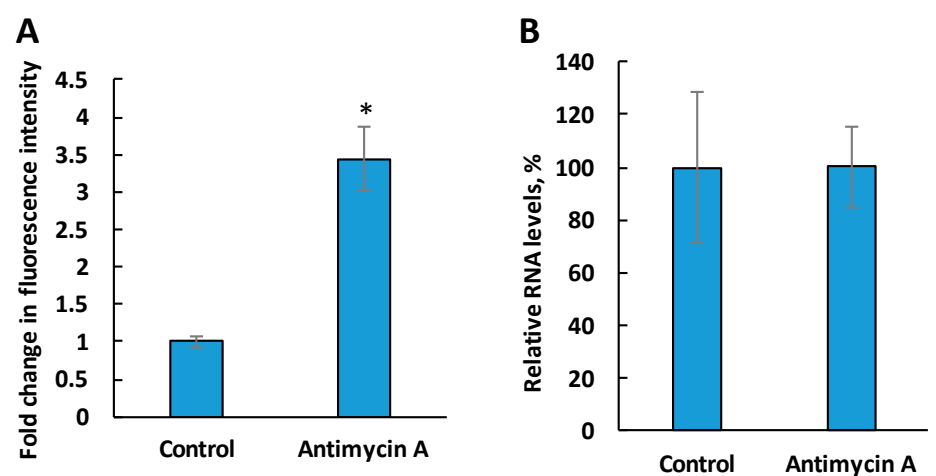

C

\begin{tabular}{|l|l|}
\hline Treatment & PI staining, \% \\
\hline Control & 0.16 \\
\hline Antimycin A & 0.17 \\
\hline
\end{tabular}

Figure 6. Mitochondrial oxidative stress induced by antimycin A does not reduce RNA levels in WT parasites. (A) WT parasites were treated with antimycin A for $3 \mathrm{~h}$ at $27^{\circ} \mathrm{C}$ and stained with $10 \mu \mathrm{M}$ of MitoSox Red. Mean fluorescence intensities were determined by flow cytometry. Relative mitochondrial ROS levels were plotted in comparison to untreated WT control cells. (B) Total RNA was extracted from $1 \times 10^{7}$ WT cells after antimycin A treatment and quantified. Percentages represent RNA levels relative to the untreated control. (C) Cell death was measured by PI staining. * $p<0.05$.

Thus, our data demonstrate that mitochondrial ROS stress is not responsible for the reduction of RNA levels in $c 14 \mathrm{dm}^{-}$mutant.

\subsection{Polysome Profiling Reveals Defects in Translation in c14dm ${ }^{-}$}

Reduced mRNA and rRNA levels support the hypothesis that mRNA translation could be compromised in the $c 14 \mathrm{dm}^{-}$mutant. To test this notion, a polysome profiling experiment was performed, which is based on monosome and polysome separation in a sucrose gradient. mRNA can be translated by more than one ribosome leading to the formation of light and heavy polysomes. A higher association of mRNAs with light and heavy polysomes supports more efficient translation, while a higher association with monosomes indicates poor translation or translational arrest, as we demonstrated earlier [25]. An equal number of cells from WT, $c 14 d^{-}$and $c 14 d m^{-} /+$C14DM were used for polysome profiling. Transcripts were stalled on ribosomes with cycloheximide [34]. Then mRNAs containing a different number of ribosomes were separated by sucrose gradient [35]. Although an equal number of cells were used in each polysome profiling, $c 14 \mathrm{dm}^{-}$mutant displays substantially reduced ribosomal peaks (Figure 7A). The heights of both monosome and polysome peaks were 30\%-40\% lower than WT and $c 14 \mathrm{dm}^{-} /+\mathrm{C} 14 \mathrm{DM}$ parasites, indicating overall reduced engagement of ribosomes in translation (Figure 7B). 
A

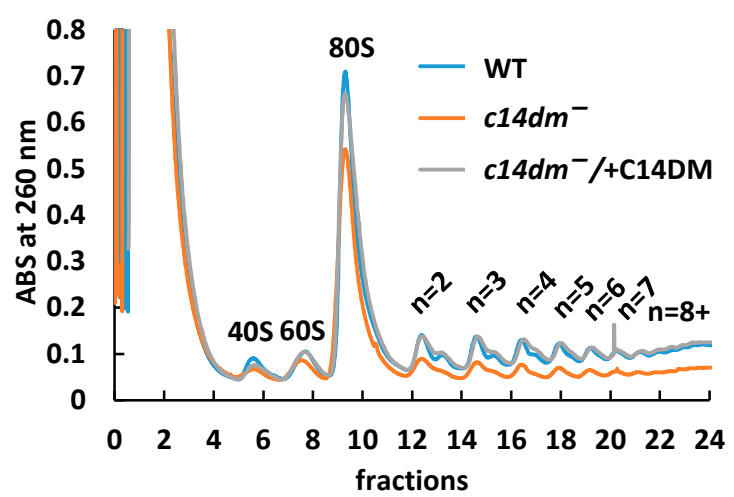

B

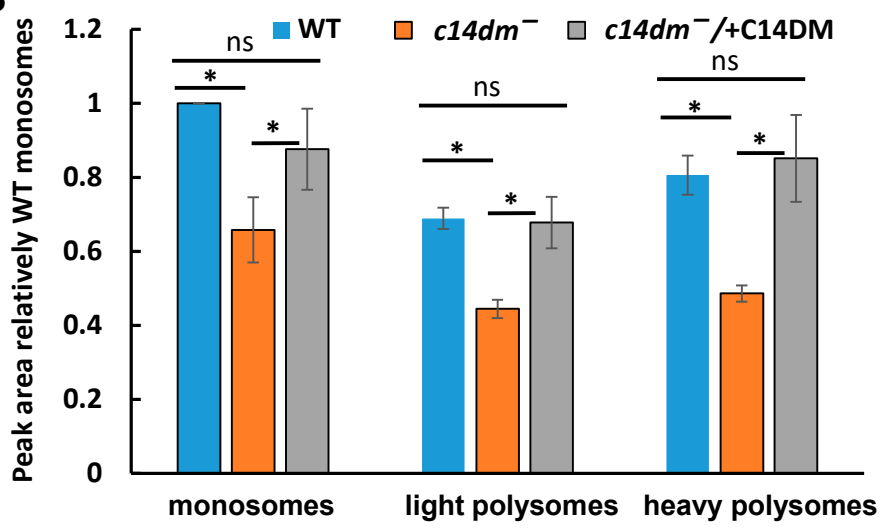

Figure 7. $\mathrm{C} 14 \mathrm{dm}^{-}$mutant displays reduced monosomal and polysomal peaks. (A) Polysomal profile of WT (blue), $c 14 d m^{-}$ (orange) and $c 14 \mathrm{dm}^{-} /+\mathrm{C} 14 \mathrm{DM}$ (grey). Ribosomal subunits and polysomes are indicated based on absorbance at $260 \mathrm{~nm}$. The experiment was conducted in four biological repeats, and one representative profile is shown here. (B) Quantification of the results shown in (A). Areas for peaks of monosomal fractions (80S), the light polysomes $(n=2-4)$ and heavy polysomes $(n=5-8+)$ were calculated using trapezoidal sum (https://bit.ly/36YJVo1 (accessed on 12 July 2020)). Peak areas were then normalized to the WT monosomes. ns: not significant; * $p<0.05$.

Next, we examined if the association of individual mRNAs with monosomes and light and heavy polysomes were affected in the $c 14 \mathrm{dm}^{-}$mutant. We expected two scenarios here: first, the association of all mRNAs with ribosomes was consistently reduced similar to the reduction in steady-state mRNA levels; alternatively, the association with ribosomes for some mRNAs could be affected more than others, leading to a global gene dysregulation instead of proportional reduction in protein production. Lower association of mRNAs with light and heavy polysomes is indicative of less efficient translation, and reductions in polysome peak heights suggested that individual RNAs could be translated less efficiently as well. Our RT-qPCR results, based on four mRNAs, demonstrate the degree of individual mRNA' association with monosomes, and light and heavy polysomes were largely unaffected by C14DM-deletion, supporting a mostly proportional reduction in protein production (Figure 8). We observed a minor increase in association with monosomes for HSP70 mRNA in $c 14 \mathrm{dm}^{-}$, but the difference was not statistically significant.

\subsection{Intensity of ER Staining Is Compromised in c14dm- under Heat Shock}

Sterol is present in both PM and organellar membranes [36]. Rough ER carries ribosomes and is where the majority of translation takes place [37]. Perturbations in sterol synthesis may alter the structure of ER and affect the recruitment of ribosomes for translation. To examine the ER in promastigotes, WT, $c 14 \mathrm{dm}^{-}$and $c 14 \mathrm{dm}^{-} /+\mathrm{C} 14 \mathrm{DM}$ parasites were grown at $27^{\circ} \mathrm{C}$ (insect vector temperature) and exposed to $37^{\circ} \mathrm{C}$ for two hours (mammalian temperature) followed by staining with the antibody against BiP, an ER protein (Figure 9). Our results indicate that BiP staining at $27^{\circ} \mathrm{C}$ was comparable between WT and $c 14 d m^{-}$. However, the $2-\mathrm{h}$ treatment at $37^{\circ} \mathrm{C}$ led to a dramatic reduction $(\sim 30 \%)$ in $c 14 \mathrm{dm}^{-}$, suggesting an altered ER at higher temperatures. 

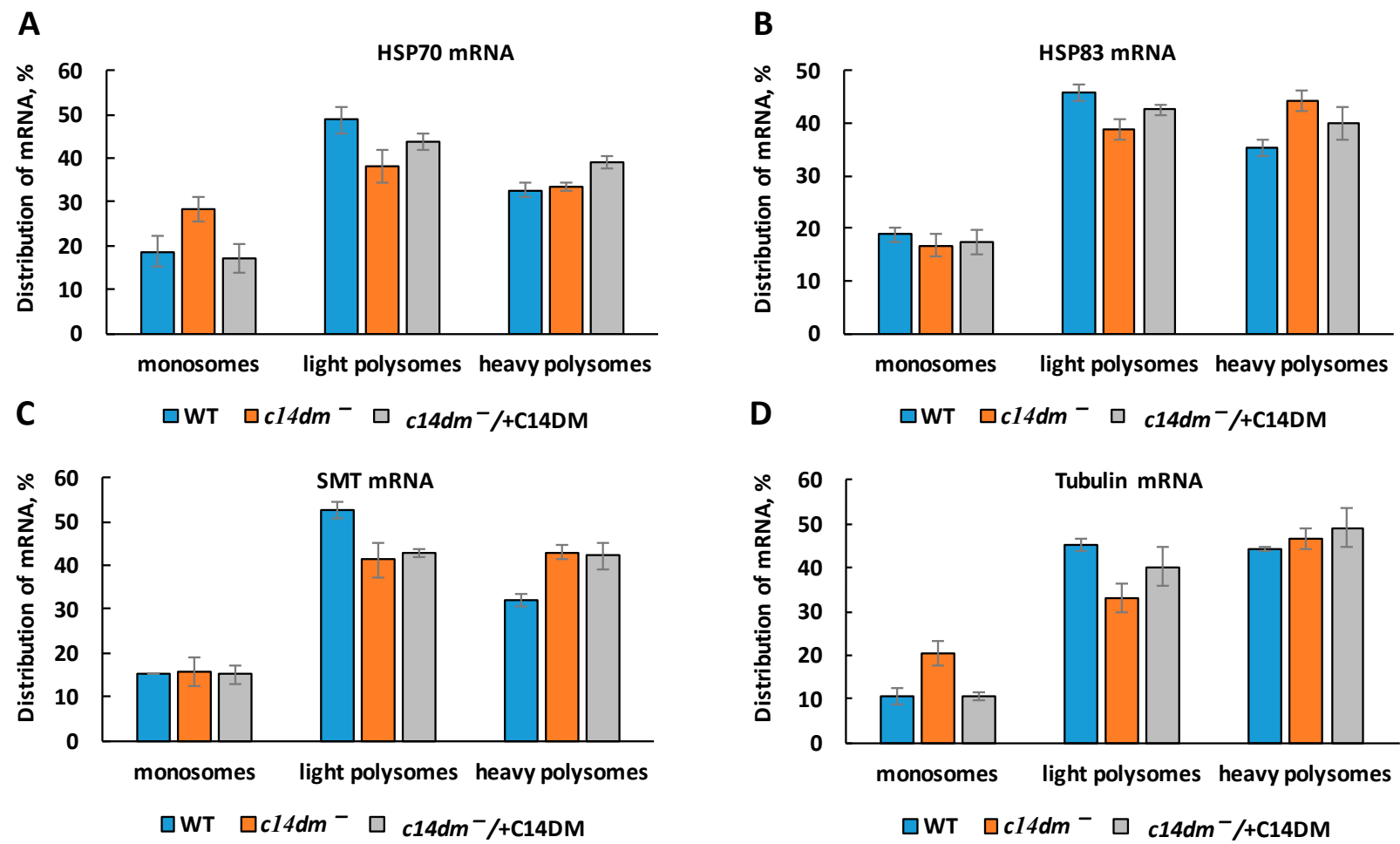

Figure 8. The association of individual mRNAs with monosomes and light and heavy polysomes is largely unaffected in $c 14 \mathrm{dm}^{-}$mutant. Distribution of HSP70 (A), HSP83 (B), SMT (C) and tubulin (D) mRNAs among monosomes, light polysomes and heavy polysomes was determined by RT-qPCR after RNA extraction from polysomal fractions.

A

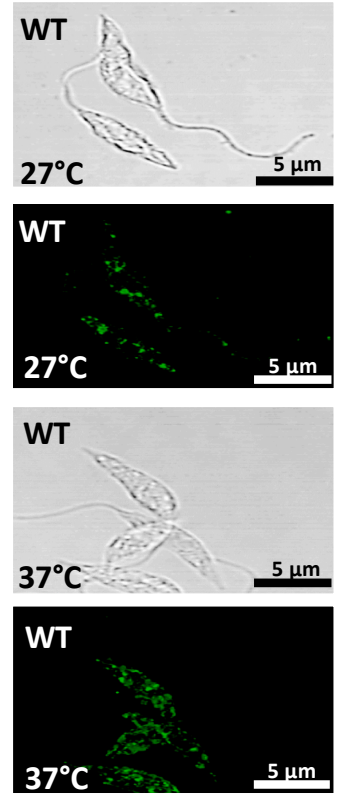

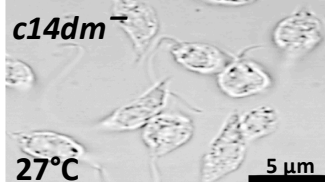
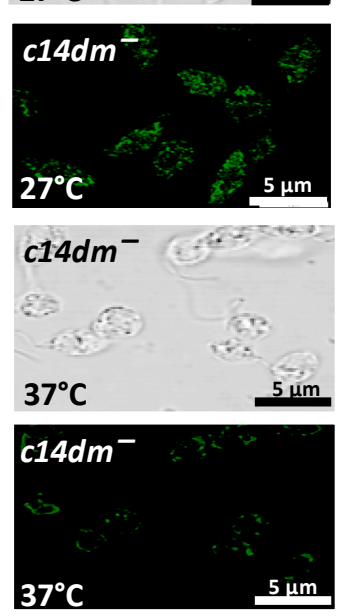

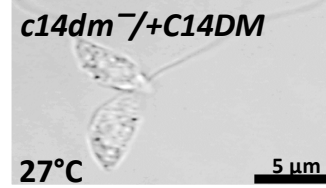

$c 14 d m-1+C 14 D M$

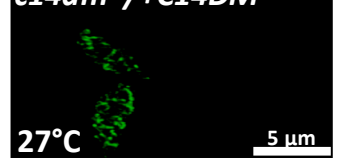

$c 14 d m /+C 14 D M$

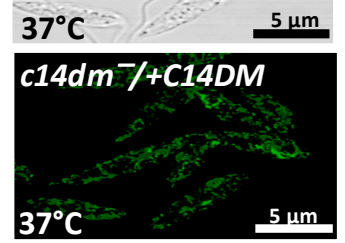

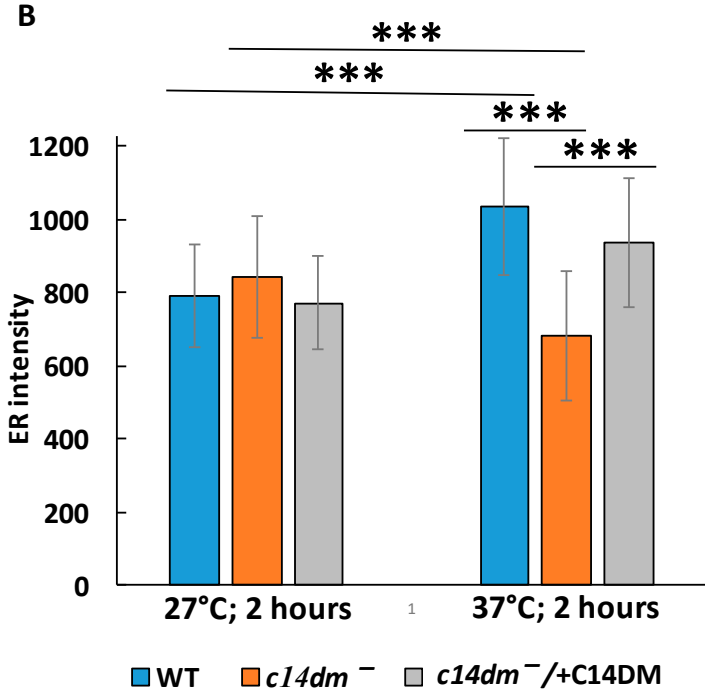

Figure 9. Heat treatment leads to a significant reduction in ER staining in $c 14 \mathrm{dm}^{-}$. (A) Representative images of WT, $c 14 d m^{-}$ and $c 14 \mathrm{dm}^{-} /+\mathrm{C} 14 \mathrm{DM}$ cells are shown. BiP staining was performed after $2 \mathrm{~h}$ of incubation at 27 or $37^{\circ} \mathrm{C}$. (B) Quantitative analysis of BiP-staining intensity. ${ }^{* *}: p<0.001$.

\section{Discussion}

Lipid homeostasis is critical for the proliferation and pathogenesis of Leishmania parasites, and changes in lipid composition can lead to multiple defects $[22,23,38-43]$. 
Despite the progress in understanding many lipid pathways, the role of sterol synthesis is not fully defined in protozoan parasites. In contrast to mammalian cells that synthesize cholesterol as the main sterol, Leishmania parasites primarily make ergosterol and 5-dehydroepisterol [44-46]. C14DM is responsible for the removal of a C-14-methyl group from sterol intermediates. Genetic deletion of this key enzyme leads to the loss of ergostanebased sterols and the accumulation of C-14-methylated sterol intermediates [22]. These defects cause increased PM fluidity and permeability. The presence of sterols is required not only in the PM but also in the membranes of intracellular organelles and lipid droplets [47]. The lack of proper sterols in $c 14 \mathrm{dm}^{-}$leads to altered mitochondrial morphology, accumulation of ROS and impairment in respiration [23].

In this study, we revealed an unexpected role of sterol synthesis in RNA stability and translation. First, we found that both total RNA and protein levels are substantially reduced in $c 14 \mathrm{dm}^{-}$mutants (Figure 1). Then, we demonstrated that all tested RNAs, including $18 \mathrm{~S}$ rRNA, 28S rRNA, tubulin and HSP83 mRNAs, display 50\%-60\% reduction in steady-state RNA levels in comparison to WT and add-back parasites when extracted from an equal number of cells (Figure 2). Next, actinomycin D treatment experiments demonstrated that both mRNA and rRNA are much less stable in the mutant and adding the C14DM gene back rescues this defect (Figure 3). In $c 14 \mathrm{dm}^{-}$, RNA instability becomes exacerbated under heat shock stress. Moreover, their response to heat shock is severely compromised, as evident from the insufficient upregulation of HSP83 and HSP70 mRNAs in $c 14 \mathrm{dm}^{-}$(Figure $4 \mathrm{~A}-\mathrm{B})$. Heat shock proteins are known to be induced in response to heat and other stress to increase cell survival under adverse conditions $[48,49]$. They act as molecular chaperones that facilitate the correct folding or degradation of misfolded proteins [50]. In addition, heat shock proteins in trypanosomatids are functionally adapted to a parasitic lifestyle, including resistance to the temperature changes and essential for the differentiation of parasites [51-53]. Our results suggest that the inability of $c 14 d m^{-}$to cope with stress is, at least in part, due to dysregulation of gene expression.

It is known that a high level of oxidative stress can contribute to increased RNA degradation and reduced translation [54-56]. We have demonstrated earlier that $c 14 \mathrm{dm}^{-}$ mutant displays mitochondrial dysfunction and elevated levels of oxidative stress [23]. However, the antioxidant treatment of the mutant with L-glutathione did not restore RNA levels (Figure 5). Moreover, the induction of oxidative stress in the mitochondrion of WT cells did not lead to RNA reduction. Thus, our data indicate that oxidative stress is not the main cause of RNA instability in $c 14 \mathrm{dm}^{-}$.

C14DM is primarily localized in the ER [22]. The lack of endogenous sterols and accumulation of abnormal, C-14-methylated intermediates may lead to defects not only in the PM but also in the ER. Rough ER contains ribosomes actively involved in translation $[57,58]$. We hypothesize that impairment in sterol production leads to significant defects in the ER (Figure 10) and reduced recruitment of ribosomes to ER where the majority of translation occurs [37]. As a result, rRNA and mRNA not involved in translation are subjected to degradation. Our polysome profiling data demonstrate that monosome and light and heavy polysome peaks are lower in $c 14 \mathrm{dm}^{-}$mutant, supporting an overall reduced engagement in translation (Figure 7). Moreover, ER staining with BiP, an ER marker, is substantially reduced (by $\sim 30 \%$ ) during heat shock, suggesting defective ER in the mutant (Figure 9). It is possible that ribosomes cannot attach sufficiently due to the alteration of sterol content in the ER. It leads to reduced translation and RNA degradation, as shown in our proposed model (Figure 10A). 
A

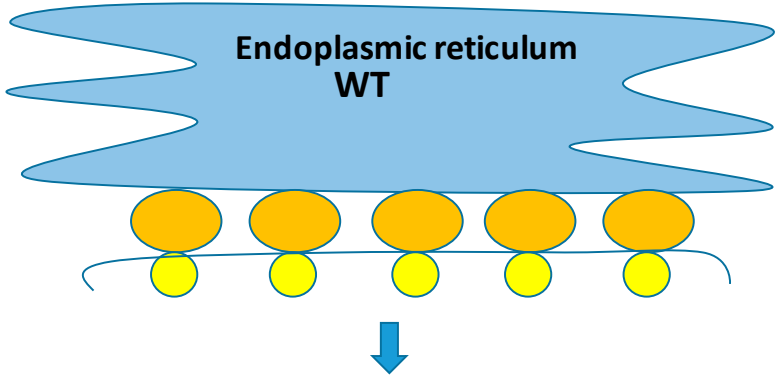

Normal turnover of RNA

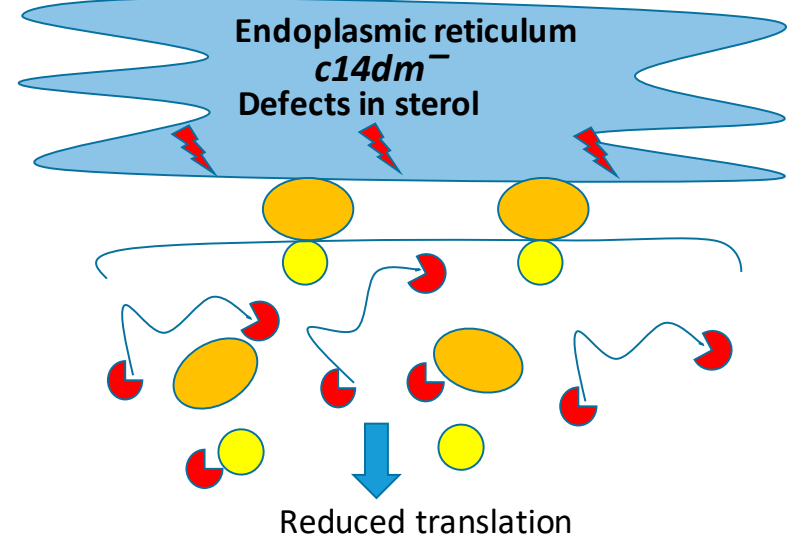

mRNA and ribosomal RNA not involved in translation are degraded WT RNA is protected by RNA binding proteins

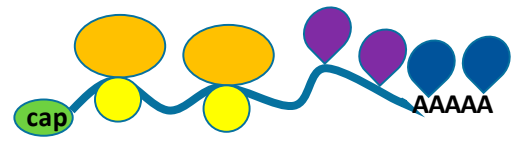

$c 14 d m^{-}$

RNA is de-protected due to the expression/traffic defects of proteins involved in RNA protection

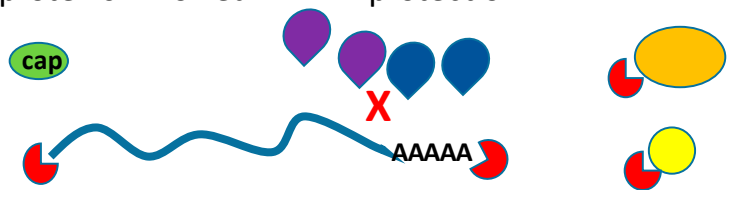

Figure 10. A model depicting the putative mechanism of RNA reduction in $c 14 \mathrm{dm}^{-}$. (A) Sterol synthesis defects may alter the lipid content of the ER and reduce ribosome recruitment, causing degradation of rRNA and mRNA not involved in translation. (B) Alternatively, defects in sterol synthesis may cause traffic defects preventing proteins involved in RNA protection from reaching and protecting RNA. Lightning bolts in red depict defects in sterol. Small (yellow) and large (orange) ovals represent small and large subunits of ribosomes, respectively. mRNA is shown as a blue line. Enzymes involved in RNA degradation are shown as partial red circles. RNA-binding proteins are shown in blue and purple.

However, we cannot rule out other possibilities. Sterol defects in other organisms are known to affect not only membrane permeability and fluidity but also the localization of membrane-bound proteins and protein transport [59]. Therefore, it is possible that defects in sterol synthesis may compromise the expression/trafficking of RNA-stabilizing proteins, thus reducing their ability to reach and protect RNA (Figure 10B).

\section{Conclusions}

The role of lipids in controlling gene expression is not sufficiently understood not only in trypanosomatids but also in other eukaryotic organisms, including mammals. In the past, lipids have been mostly viewed as components of membranes and energy storage molecules. However, during the last few decades, a substantial amount of research revealed the importance of lipids as signaling molecules regulating many processes and gene expression pathways in the cell. Sphingolipids and their metabolites, such as ceramides, sphingosine and sphingosine-1-phosphate (S1P), regulate cellular processes, including proliferation, differentiation and cell death [60-62]. The S1P acts extracellularly through cell surface receptors. It also has important intracellular targets involved in inflammation, cancer and neurodegenerative diseases $[63,64]$. Phospholipids are exceptionally important for cellular signaling, and they can modulate the activity of nuclear hormone transcription factors responsible for the tuning of genes involved in the metabolism [65]. Sterols are known to be involved in signaling as well. For example, cholesterol activates cytokine production and regulates inflammation in mammalian cells [66]. While sterols are known to serve as structural components of eukaryotic membranes and signaling molecules regulating certain pathways in the cell, they appear to play an additional unexpected role. Our study is the first of its kind and supports a novel role of sterol in RNA stability, mRNA translation and global regulation of gene expression. As a result, it shifts our 
traditional understanding of the role of lipids. For future studies, it will be very important to determine what mechanism is responsible for RNA instability caused by sterol defects. Do defects in ER and PM structures contribute to reduced RNA stability? Is the recruitment of RNA-binding proteins affected? Is ribosome recruitment to ER affected? More studies are needed to determine the role of sterols in the regulation of RNA levels and reveal the mechanism of global RNA destabilization caused by lipid imbalance. Finally, the identification of components of RNA degradation and protection machinery may provide us new drug targets, and their inhibition combined with sterol inhibition may provide a better strategy to treat leishmaniasis.

Supplementary Materials: The following are available online at https://www.mdpi.com/article/10 .3390 /biomedicines9060696/s1, Figure S1: Ribosomal RNA in $c 14 d m^{-}$degrades faster than in WT and add-back parasites, File S1: Primers used in RT-qPCR.

Author Contributions: Z.N.K. and K.Z. contributed to the conceptualization and experimental design; Z.N.K. wrote the manuscript, analyzed the data and prepared the figures; Z.N.K., S.M. (Samrat Moitra), A.P., S.M. (Sumit Mukherjee), E.B.T. and A.L.K. performed the experiments. All authors discussed and edited the manuscript. All authors have read and agreed to the published version of the manuscript.

Funding: This work was supported by the US National Institutes of Health grant AI099380 (KZ). The funder had no role in study design, data collection and analysis, decision to publish or preparation of the manuscript.

Institutional Review Board Statement: Not applicable.

Informed Consent Statement: Not applicable.

Data Availability Statement: The data presented in this study are available on request from the corresponding authors.

Acknowledgments: We thank Igor Ponomarev for providing advice on statistical analysis.

Conflicts of Interest: The authors declare no conflict of interest. The funders had no role in the design of the study; in the collection, analyses, or interpretation of data; in the writing of the manuscript, or in the decision to publish the results.

\section{References}

1. Alvar, J.; Vélez, I.D.; Bern, C.; Herrero, M.; Desjeux, P.; Cano, J.; Jannin, J.; den Boer, M.; WHO Leishmaniasis Control Team. Leishmaniasis Worldwide and Global Estimates of Its Incidence. PLoS ONE 2012, 7, e35671. [CrossRef] [PubMed]

2. Murray, H.W.; Berman, J.D.; Davies, C.R.; Saravia, N.G. Advances in leishmaniasis. Lancet 2005, 366, 1561-1577. [CrossRef]

3. Georgiadou, S.P.; Stefos, A.; Spanakos, G.; Skrimpas, S.; Makaritsis, K.; Sipsas, N.V.; Dalekos, G.N. Current clinical, laboratory, and treatment outcome characteristics of visceral leishmaniasis: Results from a seven-year retrospective study in Greece. Int. J. Infect. Dis. 2015, 34, 46-50. [CrossRef]

4. Akhoundi, M.; Downing, T.; Votypka, J.; Kuhls, K.; Lukeš, J.; Cannet, A.; Ravel, C.; Marty, P.; Delaunay, P.; Kasbari, M.; et al. Leishmania infections: Molecular targets and diagnosis. Mol. Asp. Med. 2017, 57, 1-29. [CrossRef] [PubMed]

5. Sunter, J.; Gull, K. Shape, form, function and Leishmania pathogenicity: From textbook descriptions to biological understanding. Open Biol. 2017, 7, 7. [CrossRef]

6. Zilberstein, D.; Shapira, M. The Role of $\mathrm{pH}$ and Temperature in the Development of Leishmania Parasites. Annu. Rev. Microbiol. 1994, 48, 449-470. [CrossRef] [PubMed]

7. Santos, D.O.; Coutinho, C.E.R.; Madeira, M.F.; Bottino, C.G.; Vieira, R.T.; Nascimento, S.B.; Bernardino, A.M.R.; Bourguignon, S.C.; Corte-Real, S.; Pinho, R.T.; et al. Leishmaniasis treatment-a challenge that remains: A review. Parasitol. Res. 2008, 103, 1-10. [CrossRef] [PubMed]

8. Karamyshev, A.L.; Karamysheva, Z.N. Lost in Translation: Ribosome-Associated mRNA and Protein Quality Controls. Front. Genet. 2018, 9, 431. [CrossRef] [PubMed]

9. Rodríguez, N.E.; Lockard, R.; Turcotte, E.A.; Araujo-Santos, T.; Bozza, P.T.; Borges, V.; Wilson, M. Lipid bodies accumulation in Leishmania infantum -infected C57BL/ 6 macrophages. Parasite Immunol. 2017, 39, e12443. [CrossRef] [PubMed] 
10. Rabhi, S.; Rabhi, I.; Trentin, B.; Piquemal, D.; Regnault, B.; Goyard, S.; Lang, T.; Descoteaux, A.; Enninga, J.; Guizani-Tabbane, L. Lipid Droplet Formation, Their Localization and Dynamics during Leishmania major Macrophage Infection. PLoS ONE 2016, 11, e0148640. [CrossRef] [PubMed]

11. Messaoud, H.B.-B.; Guichard, M.; Lawton, P.; Delton, I.; Azzouz-Maache, S. Changes in Lipid and Fatty Acid Composition During Intramacrophagic Transformation of Leishmania donovani Complex Promastigotes into Amastigotes. Lipids 2017, 52, 433-441. [CrossRef]

12. Armitage, E.G.; Alqaisi, A.Q.I.; Godzien, J.; Peña, I.; Mbekeani, A.J.; Alonso-Herranz, V.; López-Gonzálvez, Á.; Martín, J.; Gabarro, R.; Denny, P.W.; et al. Complex Interplay between Sphingolipid and Sterol Metabolism Revealed by Perturbations to the Leishmania Metabolome Caused by Miltefosine. Antimicrob. Agents Chemother. 2018, 62. [CrossRef] [PubMed]

13. Guarnizo, S.G.; Tikhonova, E.; Zabet-Moghaddam, M.; Zhang, K.; Muskus, C.; Karamyshev, A.; Karamysheva, Z. Drug-Induced Lipid Remodeling in Leishmania Parasites. Microorganisms 2021, 9, 790. [CrossRef] [PubMed]

14. McCall, L.-I.; El Aroussi, A.; Choi, J.Y.; Vieira, D.F.; De Muylder, G.; Johnston, J.B.; Chen, S.; Kellar, D.; Siqueira-Neto, J.; Roush, W.R.; et al. Targeting Ergosterol Biosynthesis in Leishmania donovani: Essentiality of Sterol 14alpha-demethylase. PLoS Negl. Trop. Dis. 2015, 9, e0003588. [CrossRef] [PubMed]

15. Yao, C.; Wilson, M.E. Dynamics of sterol synthesis during development of Leishmania spp. parasites to their virulent form. Parasites Vectors 2016, 9, 200. [CrossRef]

16. Torres-Santos, E.C.; Sampaio-Santos, M.I.; Buckner, F.; Yokoyama, K.; Gelb, M.; Urbina, J.A.; Rossi-Bergmann, B. Altered sterol profile induced in Leishmania amazonensis by a natural dihydroxymethoxylated chalcone. J. Antimicrob. Chemother. 2009, 63, 469-472. [CrossRef]

17. Drin, G. Topological Regulation of Lipid Balance in Cells. Annu. Rev. Biochem. 2014, 83, 51-77. [CrossRef]

18. Woodman, B.S.; Trousdale, C.; Conover, J.; Kim, K.; Woodman, S. Yeast membrane lipid imbalance leads to trafficking defects toward the Golgi. Cell Biol. Int. 2018, 42, 890-902. [CrossRef]

19. Maxfield, F.; Mondal, M. Sterol and lipid trafficking in mammalian cells. Biochem. Soc. Trans. 2006, 34, 335-339. [CrossRef]

20. Georgiev, A.G.; Johansen, J.; Ramanathan, V.D.; Sere, Y.Y.; Beh, C.T.; Menon, A.K. Arv1 Regulates PM and ER Membrane Structure and Homeostasis But is Dispensable for Intracellular Sterol Transport. Traffic 2013, 14, 912-921. [CrossRef]

21. Lepesheva, G.I.; Hargrove, T.Y.; Kleshchenko, Y.; Nes, W.D.; Villalta, F.; Waterman, M.R. CYP51: A Major Drug Target in the Cytochrome P450 Superfamily. Lipids 2008, 43, 1117-1125. [CrossRef]

22. Xu, W.; Hsu, F.-F.; Baykal, E.; Huang, J.; Zhang, K. Sterol Biosynthesis Is Required for Heat Resistance but Not Extracellular Survival in Leishmania. PLoS Pathog. 2014, 10, e1004427. [CrossRef] [PubMed]

23. Mukherjee, S.; Moitra, S.; Xu, W.; Hernandez, V.; Zhang, K. Sterol 14- $\alpha$-demethylase is vital for mitochondrial functions and stress tolerance in Leishmania major. PLoS Pathog. 2020, 16, e1008810. [CrossRef]

24. Kapler, G.M.; Coburn, C.M.; Beverley, S.M. Stable transfection of the human parasite Leishmania major delineates a 30-kilobase region sufficient for extrachromosomal replication and expression. Mol. Cell. Biol. 1990, 10, 1084-1094. [CrossRef] [PubMed]

25. Karamysheva, Z.N.; Tikhonova, E.; Grozdanov, P.N.; Huffman, J.C.; Baca, K.R.; Karamyshev, A.; Denison, R.B.; MacDonald, C.C.; Zhang, K.; Karamyshev, A.L. Polysome Profiling in Leishmania, Human Cells and Mouse Testis. J. Vis. Exp. 2018, e57600. [CrossRef] [PubMed]

26. Schmittgen, T.D.; Livak, K.J. Analyzing real-time PCR data by the comparative $\mathrm{C}_{\mathrm{T}}$ method. Nat. Protoc. 2008, 3, 1101-1108. [CrossRef]

27. Wolf, S.F.; Schlessinger, D. Nuclear metabolism of ribosomal RNA in growing, methionine-limited, and ethionine-treated HeLa cells. Biochemistry 1977, 16, 2783-2791. [CrossRef]

28. Waldron, C.; Lacroute, F. Effect of growth rate on the amounts of ribosomal and transfer ribonucleic acids in yeast. J. Bacteriol. 1975, 122, 855-865. [CrossRef]

29. Bensaude, O. Inhibiting eukaryotic transcription. Which compound to choose? How to evaluate its activity? Transcription 2011, 2, 103-108. [CrossRef]

30. LaRiviere, F.J.; Cole, S.E.; Ferullo, D.J.; Moore, M.J. A Late-Acting Quality Control Process for Mature Eukaryotic rRNAs. Mol. Cell 2006, 24, 619-626. [CrossRef]

31. Pestov, D.G.; Shcherbik, N. Rapid Cytoplasmic Turnover of Yeast Ribosomes in Response to Rapamycin Inhibition of TOR. Mol. Cell. Biol. 2012, 32, 2135-2144. [CrossRef]

32. Kramer, S.; Queiroz, R.; Ellis, L.; Webb, H.; Hoheisel, J.D.; Clayton, C.; Carrington, M. Heat shock causes a decrease in polysomes and the appearance of stress granules in trypanosomes independently of eIF2 $\alpha$ phosphorylation at Thr169. J. Cell Sci. 2008, 121, 3002-3014. [CrossRef]

33. Alves, S.G.L.R. RNA-binding proteins related to stress response and differentiation in protozoa. World J. Biol. Chem. 2016, 7, 78-87. [CrossRef]

34. Ennis, H.L.; Lubin, M. Cycloheximide: Aspects of Inhibition of Protein Synthesis in Mammalian Cells. Science 1964, 146, 1474-1476. [CrossRef]

35. Gandin, V.; Sikström, K.; Alain, T.; Morita, M.; McLaughlan, S.; Larsson, O.; Topisirovic, I. Polysome Fractionation and Analysis of Mammalian Translatomes on a Genome-wide Scale. J. Vis. Exp. 2014, e51455. [CrossRef] 
36. Hannich, J.T.; Umebayashi, K.; Riezman, H. Distribution and Functions of Sterols and Sphingolipids. Cold Spring Harb. Perspect. Biol. 2011, 3, a004762. [CrossRef]

37. Reid, D.W.; Nicchitta, C.V. Primary Role for Endoplasmic Reticulum-bound Ribosomes in Cellular Translation Identified by Ribosome Profiling. J. Biol. Chem. 2012, 287, 5518-5527. [CrossRef]

38. Zhang, K.; Pompey, J.M.; Hsu, F.-F.; Key, P.; Bandhuvula, P.; Saba, J.D.; Turk, J.; Beverley, S.M. Redirection of sphingolipid metabolism toward de novo synthesis of ethanolamine in Leishmania. EMBO J. 2007, 26, 1094-1104. [CrossRef] [PubMed]

39. Mukherjee, S.; Xu, W.; Hsu, F.-F.; Patel, J.; Huang, J.; Zhang, K. Sterol methyltransferase is required for optimal mitochondrial function and virulence inLeishmania major. Mol. Microbiol. 2018, 111, 65-81. [CrossRef] [PubMed]

40. Moitra, S.; Pawlowic, M.C.; Hsu, F.-F.; Zhang, K. Phosphatidylcholine synthesis through cholinephosphate cytidylyltransferase is dispensable in Leishmania major. Sci. Rep. 2019, 9, 7602. [CrossRef] [PubMed]

41. Pawlowic, M.C.; Hsu, F.-F.; Moitra, S.; Biyani, N.; Zhang, K. Plasmenylethanolamine synthesis inLeishmania major. Mol. Microbiol. 2016, 101, 238-249. [CrossRef]

42. Moitra, S.; Basu, S.; Pawlowic, M.; Hsu, F.-F.; Zhang, K. De Novo Synthesis of Phosphatidylcholine Is Essential for the Promastigote But Not Amastigote Stage in Leishmania major. Front. Cell. Infect. Microbiol. 2021, 11, 647870. [CrossRef] [PubMed]

43. Ning, Y.; Frankfater, C.; Hsu, F.-F.; Soares, R.P.; Cardoso, C.A.; Nogueira, P.M.; Lander, N.M.; Docampo, R.; Zhang, K. Lathosterol Oxidase (Sterol C-5 Desaturase) Deletion Confers Resistance to Amphotericin B and Sensitivity to Acidic Stress in Leishmania major. mSphere 2020, 5. [CrossRef] [PubMed]

44. Goad, L.; Holz, G.G.; Beach, D.H. Sterols of Leishmania species, implications for biosynthesis. Mol. Biochem. Parasitol. 1984, 10, 161-170. [CrossRef]

45. Urbina, J.A. Lipid biosynthesis pathways as chemotherapeutic targets in kinetoplastid parasites. Parasitology 1997, 114, 91-99. [CrossRef]

46. Urbina, J.A.; Vivas, J.; Lazardi, K.; Molina, J.; Payares, G.; Pirns, M.M.; Piras, R. Antiproliferative Effects of $\triangle 24(25)$ Sterol Methyl Transferase Inhibitors on Trypanosoma (Schizotrypanum) cruzi: In vitro and in vivo Studies. Chemotherapy 1996, 42, 294-307. [CrossRef] [PubMed]

47. Maxfield, F.R.; Menon, A.K. Intracellular sterol transport and distribution. Curr. Opin. Cell Biol. 2006, 18, 379-385. [CrossRef] [PubMed]

48. Vonlaufen, N.; Kanzok, S.M.; Wek, R.C.; Jr, W.J.S. Stress response pathways in protozoan parasites. Cell. Microbiol. 2008, 10, 2387-2399. [CrossRef] [PubMed]

49. Folgueira, C.; Requena, J.M. A postgenomic view of the heat shock proteins in kinetoplastids. FEMS Microbiol. Rev. 2007, 31, 359-377. [CrossRef] [PubMed]

50. Mayer, M.P.; Bukau, B. Hsp70 chaperones: Cellular functions and molecular mechanism. Cell. Mol. Life Sci. 2005, 62, 670-684. [CrossRef] [PubMed]

51. Shonhai, A.; Maier, A.G.; Przyborski, J.M.; Blatch, G.L. Intracellular protozoan parasites of humans: The role of molecular chaperones in development and pathogenesis. Protein Pept. Lett. 2011, 18, 143-157. [CrossRef]

52. Minia, I.; Merce, C.; Terrao, M.; Clayton, C. Translation Regulation and RNA Granule Formation after Heat Shock of Procyclic Form Trypanosoma brucei: Many Heat-Induced mRNAs Are also Increased during Differentiation to Mammalian-Infective Forms. PLoS Negl. Trop. Dis. 2016, 10, e0004982. [CrossRef]

53. Gitau, G.W.; Mandal, P.; Blatch, G.L.; Przyborski, J.M.; Shonhai, A. Characterisation of the Plasmodium falciparum Hsp70-Hsp90 organising protein (PfHop). Cell Stress Chaperon 2012, 17, 191-202. [CrossRef] [PubMed]

54. Shenton, D.; Smirnova, J.B.; Selley, J.N.; Carroll, K.; Hubbard, S.J.; Pavitt, G.; Ashe, M.P.; Grant, C.M. Global Translational Responses to Oxidative Stress Impact upon Multiple Levels of Protein Synthesis. J. Biol. Chem. 2006, 281, 29011-29021. [CrossRef] [PubMed]

55. Wurtmann, E.J.; Wolin, S. RNA under attack: Cellular handling of RNA damage. Crit. Rev. Biochem. Mol. Biol. 2009, 44, 34-49. [CrossRef] [PubMed]

56. Li, Z.; Wu, J.; DeLeo, C.J. RNA damage and surveillance under oxidative stress. IUBMB Life 2006, 58, 581-588. [CrossRef] [PubMed]

57. Redman, C.M. Biosynthesis of Serum Proteins and Ferritin by Free and Attached Ribosomes of Rat Liver. J. Biol. Chem. 1969, 244, 4308-4315. [CrossRef]

58. Hicks, S.J.; Drysdale, J.W.; Munro, H.N. Preferential Synthesis of Ferritin and Albumin by Different Populations of Liver Polysomes. Science 1969, 164, 584-585. [CrossRef] [PubMed]

59. Casares, D.; Escribá, P.V.; Rosselló, C.A. Membrane Lipid Composition: Effect on Membrane and Organelle Structure, Function and Compartmentalization and Therapeutic Avenues. Int. J. Mol. Sci. 2019, 20, 2167. [CrossRef] [PubMed]

60. Torres, M.; Rosselló, C.A.; Fernández-García, P.; Lladó, V.; Kakhlon, O.; Escribá, P.V. The Implications for Cells of the Lipid Switches Driven by Protein-Membrane Interactions and the Development of Membrane Lipid Therapy. Int. J. Mol. Sci. 2020, 21, 2322. [CrossRef] [PubMed] 
61. Ohanian, J.; Ohanian, V. Sphingolipids in mammalian cell signalling. Cell. Mol. Life Sci. 2001, 58, 2053-2068. [CrossRef] [PubMed]

62. Maceyka, M.; Harikumar, K.; Milstien, S.; Spiegel, S. Sphingosine-1-phosphate signaling and its role in disease. Trends Cell Biol. 2012, 22, 50-60. [CrossRef]

63. Nagahashi, M.; Abe, M.; Sakimura, K.; Takabe, K.; Wakai, T. The role of sphingosine-1-phosphate in inflammation and cancer progression. Cancer Sci. 2018, 109, 3671-3678. [CrossRef] [PubMed]

64. Maceyka, M.; Spiegel, S. Sphingolipid metabolites in inflammatory disease. Nat. Cell Biol. 2014, 510, 58-67. [CrossRef] [PubMed]

65. Musille, P.M.; Kohn, J.A.; Ortlund, E.A. Phospholipid - Driven gene regulation. FEBS Lett. 2013, 587, 1238-1246. [CrossRef] [PubMed]

66. Fessler, M.B.; Parks, J.S. Intracellular Lipid Flux and Membrane Microdomains as Organizing Principles in Inflammatory Cell Signaling. J. Immunol. 2011, 187, 1529-1535. [CrossRef] 